ISPEC Tarım Bilimleri Dergisi

$2020: 4(1)$

(C) Telif hakk ISPEC'e aittir

Arasturma Makalesi

\section{*Nil GÜREL}

Orcid No: 0000-0001-1560-2574

\section{**Mustafa OKANT}

Orcid No: 0000-0002-8159-2444

*Harran Üniversitesi Fen Bilimleri

Enstitüsü

gurel@hotmail.com

**Harran Üniversitesi Ziraat

Fakültesi Tarla Bitkileri Bölümü

(Sorumlu yazar)

mokant63@yahoo.com

NOT: Bu çalışma, ilk yazarın yüksek lisans verilerinden üretilmiştir.

DOI

https://doi.org/10.46291/ISPECJASv ol4iss1pp31-41

Geliş Tarihi: 14/01/2020

Kabul Tarihi: 22/02/2020

\section{Anahtar Kelimeler \\ Mısır, börülce ve birlikte yetiştirme}

\section{Keywords}

Corn, Vigna sinensis L and intercropping www.ispecjournal.com

\section{$\underline{\text { Research Article }}$}

Mısır (Zea mays l.) ve Börülce (Vigna sinensis l. )'nin İkinci Ürün Olarak Birlikte Yetiştirmenin Yeşil Ot Verimi ve Bazı Tarımsal Karakterlere Etkilerinin Araştırılması

Özet

Güneydoğu Anadolu'da, hâsıl amacı olarak birlikte yetiştirilen mısır ve börülcenin farklı ekim sistemlerinde bazı tarımsal karakterler ile kalite özelliğine etkisini incelemek amacıyla yürütülen bu çalışmada, incelenen özellikler koçan oranı hariç birlikte üretim sistemlerinden önemli ölçüde etkilenmiştir. İkinci üründe börülce veriminin azaldığı, mısır yeşil ot veriminin $\operatorname{arttığ} 1$, alan kullanım etkinliğinin bir ölçüsü olan LER'in karışım ekimlerde kaynakları daha etkin kullanmasından kaynaklanabilmektedir.

Corn (Zea mays L.) and Vigna (Vıgna sinensis L. ) Double Crop and Effects of Intercropping on Biomas Yield and Related Charecters were Evaluated

\section{Abstract}

This Study was conducted to determine yield and yield component of various maize+cowpea intercropping systems under Southeastern Anatolia conditions. The planting paterns have significntly affected all characters studied and ear ratio except When intercropping the secand fresh yield of cowpea decreased. However, fresh yield of maize were increased. When the intercropping is used, LER (Land Equivalent Ratio) values, which is the measurement of producttivity by intercropping utilize the current environmental resourches more gain fully 


\section{GİRIŞ}

Mısır ve börülcenin birlikte üretimi, Batı Afrika da yaygın olarak kullanılmaktadır. $\mathrm{Bu}$ üretim şekli birim alandan elde edilen toplam verimi artırdığı saptanmıştır. Verimlilik, bu iki bitkinin doğal kaynaklara en fazla ihtiyaç duydukları dönemin farklı olması nedeniyle artmaktadır. Ayrıca, bitki besin elementleri ve 1şı̆̆a en yüksek talebin misır da ekimden sonra 56 günde, börülcede ise ekimden sonra 56-120 gün arasında ortaya çıktığını göstermiştir (Haitzel, 1974). Misır + börülcenin su kullanım etkinliği konusunda çok az araştırma sonucu mevcut olmasına karşın, mısır + soya, mısır + V.radiata karışımlarında safa göre su kullanım etkinliği bakımından daha yüksek değerler saptanmıştır (De ve Singh, 1981). Diğer türlerin birlikte üretiminde ayrıca su kullanım etkinliğinin arttığı bilinmektedir. Güneydoğu Anadolu Bölgesinde yapılan bazı çalışmalar incelendiğinde; (Seydoşoğlu ve Saruhan 2017) Diyarbakır ekolojik koşullarında yeşil ot verimini ortalama $8341.33 \mathrm{~kg} / \mathrm{da}$, Çelik ve Bengisu (2019), Harran ovası koşullarında bitki boyu değerini ortalama $180.58 \mathrm{~cm}$, Y1ldırım ve Bengisu (2019) Şanlıurfa ekolojik koşullarında bitki boyunu ortalama $285 \mathrm{~cm}$, Seydoşoğlu ve Cengiz (2020), Siirt ekolojik koşullarında $9116.67 \mathrm{~kg} / \mathrm{da}$, (Sarikurt ve
Bengisu, 2020) Diyarbakır koşullarında misır bitkisinde bitki boyunu ortalama $273.33 \mathrm{~cm}$ olduğunu, Bengisu ve Baytekin (2020a) Şanlıurfa ekolojik koşullarında bitki boyunu ortalama $258.86 \mathrm{~cm}$, Bengisu ve Baytekin (2020b) Şanliurfa ekolojik koşullarında bitki boyunu ortalama $222 \mathrm{~cm}$ olarak tespit etmiştir.

$\mathrm{Bu}$ çalışma, Güneydoğu bölgesinde misır + börülcenin birlikte yetiştirilmesinin hâsıl olarak bazı tarımsal karakterlere etkisinin saptanması amacıyla yapılmıştır.

\section{MATERYAL ve YÖNTEM}

Araştırmada materyal olarak Dekalp şirketinden sağlanan silajlık C 955 misır hibrit çeşidi ile yerel börülce (Vigna sinensis L.) çeşiti materyal olarak kullanılacaktır. Çeşidin bölgede yapılan adaptasyon çalışmalarında yüksek verimi ve adaptasyon yeteneği dikkat çekmiştir. Deneme yeri topraklarının ana materyali kolluviyal olup, kırmızımsı kahverengi derin toprak özelliğindedir. Yapılan analizler sonucunda deneme yeri topraklarının ağır bünyeli, tuzlulukları zararsız, hafif alkali reaksiyonda, kireçli, organik madde yönünden fakir, fosforca yetersiz, potasyumca zengin durumda olduğu bulunmuştur (Dinç ve ark., 1988). Şanlıurfa ilinin 2002 yılına ilişkin iklim değerleri Şekil 1'de görülmektedir 
(Anonim, 2002). Deneme y1lına ait en yüksek sıcaklık Temmuz ayı'nda, en yüksek ortalama sıcaklık yine aynı ayda ve en düşük sıcaklık ise Kasım ayında ölçülmüştür. Ortalama nispi nem en düşük Temmuz, en yüksek Kasım ayı'nda tespit edilmiştir. Yağış toplamı Ağustos ayı'da hiç görülmez iken, Kasım ayı'nda en yüksek seviyede olmuştur. Yağışlı gün sayısı değerlerine bakıldığında, Ağustos ayı'nda hiç yağış kaydedilmezken en fazla yağışlı gün sayısı Ekim ayı'da gözlenmiştir. Uzun yı1lar ortalama değerleri de aynı doğrultuda izlenebilir.

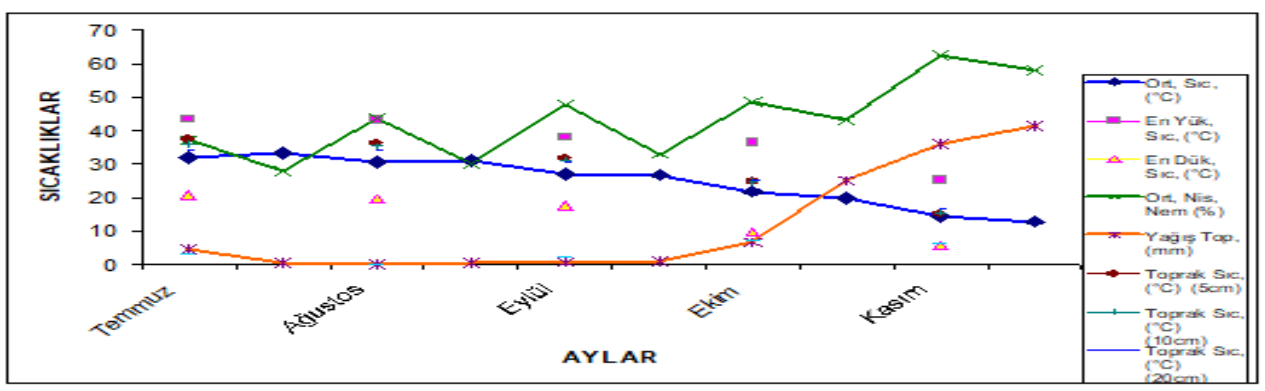

Şekil 1. Deneme yılına ait Şanlıurfa ili iklim değerleri

$\mathrm{Bu}$ araştırma; hâsıl (yeşil ot) amacıyla 2002 yılında ikinci ürün olarak Harran Üniversitesi Ziraat Fakültesi, araştırma alanında bölünmüş parseller deneme deseninde üç tekrarlamalı olarak kurulmuştur. Birlikte yetiştirmede (birlikte ekim=intercropping) uygulanan ekim sistemleri ve dekarda bitki sayıları ile fizyolojik devreleri (alt ve ana parseller) Çizelge 1'de verilmiştir.

Çizelge 1. Ekim sistemleri, dekara bitki sayıları ve fizyolojik devreleri

\begin{tabular}{lcccc}
\hline $\begin{array}{l}\text { Uygulamalar Ekim Sistemleri } \\
\text { (alt parsel) }\end{array}$ & \multicolumn{2}{c}{$\begin{array}{l}\text { Sira aras1 x Sira Üzeri (cm) } \\
\text { Misı̈r }\end{array}$} & Börülce & \multicolumn{2}{c}{ Dekarda Bitki Sayıs1 (adet) } \\
1. Saf Börülce & ----- & $35 \times 5.0$ & ----- & Börülce \\
2. Saf Misır & $70 \times 15$ & ----- & 4762 & -28575 \\
3. 1 Misır+1 Börülce & $70 \times 15$ & $35 \times 5.0$ & 4762 & 28575 \\
4- 1 Misır+2 Börülce & $70 \times 15$ & $35 \times 5.0$ & 4762 & 28575 \\
5- 2 Misır+1 Börülce & $70 \times 15$ & $35 \times 5.0$ & 4762 & 28575 \\
6- 2 Misır+2 Börülce & $70 \times 15$ & $35 \times 5.0$ & 4762 & 28575 \\
7- Misır/Börülce & $70 \times 30$ & $70 \times 30$ & 2381 & 2381 \\
\hline
\end{tabular}

Hasat Zamanları (ana parsel)

\footnotetext{
1-Tepe Püskülü Çıkışı

2-Süt Olum Devresi

3-Hamur Olum Devresi
} 
Ekimde parsel alanı 1, 2, 3, 4, 5 ve 7 . sistemlerde $6 \times 5.6=33.6 \mathrm{~m}^{2}, 6$. sistemde ise $(2 \mathrm{M}+2 \mathrm{~B}) 6 \times 7=42 \mathrm{~m}^{2}$ olup, her parselde kenar etkisini gidermek için, parsel başlarından yarımşar metre, blok kenarlarından birer ekim birimi atılarak hasat yapılacağından hasat alanı $5 \times 4.2=$ $21.0 \mathrm{~m}^{2}$, diğer parselde $(2 \mathrm{M}+2 \mathrm{~B}) 5 \times 5.6=$ $28.0 \mathrm{~m}^{2}$ olarak alınmıştır. Denemede ikinci ürün için buğday hasadından sonra anız uzaklaştırılıp, toprak pullukla derin sürülüp yabancı ot ilacı ile ilaçlanmış iki kez diskaro çekilip tapanla düzeltilerek ekime hazır hale getirilmiştir. Ekimden önce taban gübresi olarak hem saf hem de birlikte ekilen misıra dekara $10 \mathrm{~kg}$ saf azot ve $10 \mathrm{~kg}$ saf fosfor gelecek şekilde, $\% 20$ azot ve $\% 20$ fosfor bulunan kompoze gübre verilmiştir. Bitkiler 50-60 cm boylandığında, dekara $10 \mathrm{~kg}$ azot gelecek şekilde \%26 azot içeren amonyum nitrat gübresi sıralar arasına elle verilerek (banda) toprağa karıştırılmıştır. Saf ekilecek börülceye ekimden önce dekara 5 $\mathrm{kg}$ saf azot, $5 \mathrm{~kg}$ saf fosfor verilmiştir. Ekimi: İkinci ürün ekimi Temmuz'un ilk haftası yapılmıştır. Ekim kuruya yapıldığından çıkış için gerekli nem yağmurlama sulama ile giderilmiştir. Çıkıştan sonra seyreltme yapılıp istenilen bitki sıklıkları sağlanmıştır. Yetiştirme süresince gerekli bakım işlemleri yürütülmüşsür. Hasat; yeşil ot amacıyla mısır bitkisi ölçü alınıp, tepe püskülü, süt olum ve hamur olum devrelerinde yapılmıştır.

İncelenen özellikler incelendiğinde; mısır bitkisinde bitki boyu, sap çapı, yeşil ve kuru ot verimleri, yaprak, sap ve koçan oranları ile ham protein verimleri tespit edilmiştir. Börülcede ise bitki boyu, dal sayısı, yeşil ve kuru ot verimleri, alan eşdeğerlik oranları hesaplanmıştır.

\section{Verilerin Değerlendirilmesi}

Araştırma sonunda elde edilen veriler, bölünmüş parseller deneme metoduna göre MSTATC paket programı kullanılarak test edilmiştir.

\section{BULGULAR ve TARTIŞMA Misır Bitkisinde Bitki Boyu}

Bitki boyu değerlerinin karışım ekimden etkilendiği, aralarındaki farkın önemli olduğu Şekil 2'den izlenmektedir. Anılan karakterde ortalama değerin $234.80 \mathrm{~cm}$ ile tüm hasat zamanlarında en yüksek misır/börülce karışımında bulunmuştur. En düşük ortalama değer ise $209.20 \mathrm{~cm}$ ile 2 misır+1börülce'de ortaya çıkmıştır. Mısır/börülce sisteminde daha yüksek değerler elde edilmesi, bu karakter açısından tür içi rekabetin, türler arası rekabetten daha etkin olması ile açıklanabilir. 


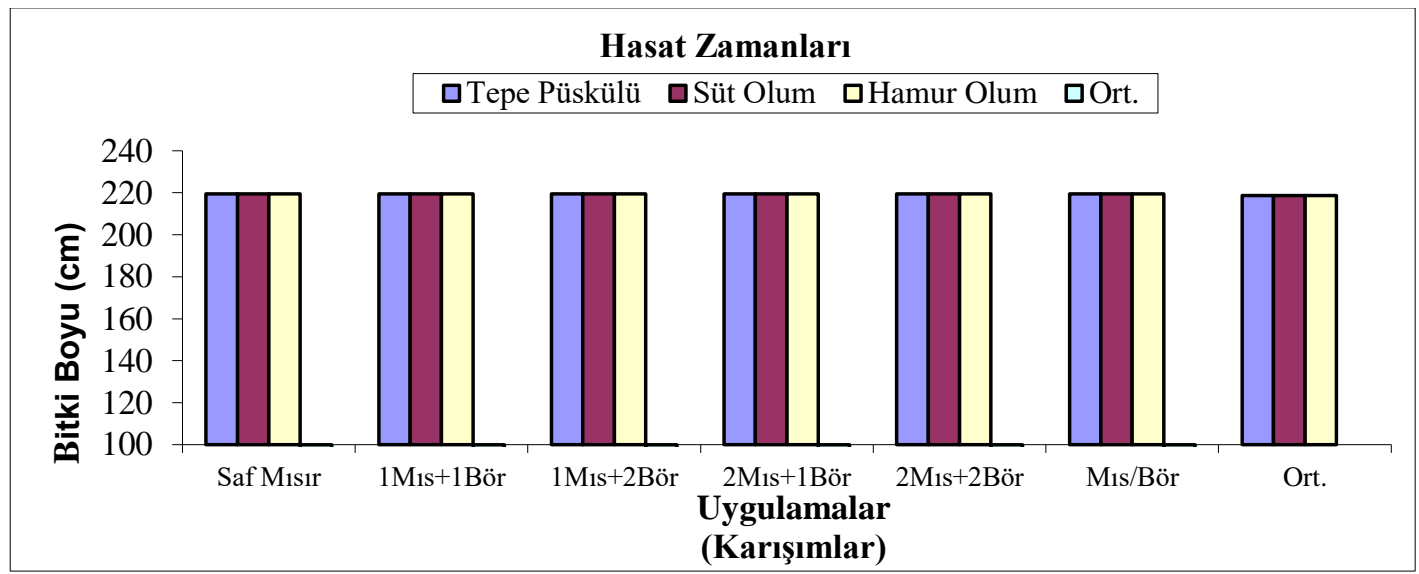

Şekil 2. Birlikte yetiştirme sistemlerinde ikinci ürün hâsıl mısırda bitki boyu $(\mathrm{cm})$ değerleri

\section{Bitki Çapı}

Uygulamalar dikkate alındığında bitki çap1 değerinin birlikte yetiştirme sisteminden etkilenmediği tespit edilmiştir.

\section{Yeşil Ot Verimi}

Yeşil ot verimi karakteri bakımından $\mathrm{F}$ testine göre hasat zamanının $(\mathrm{P}<0.05)^{\text {' de, }}$ uygulamalar arasındaki farkın ise çok önemli olduğu izlenmektedir $(\mathrm{P}<0.01)$.

Şekil 3'te, yeşil ot verimi karakterinin yapılan L.S.D testinde $778.30(\mathrm{~kg} / \mathrm{da})$ en yüksek hasat zamanının süt olum devresinde, en yüksek birlikte yetiştirme sisteminin 1mısır+1börülce, saf misır, 2misır+1börülce, misır/börülce ve 1mısır+2börülcede olduğu gözlemlenmiştir. Anılan sistemlerde daha yüksek hasıl verimi elde edilmesi, hasıl veriminde yaprak ve sap oranlarının önemli bir kriter olduğunu göstermektedir.

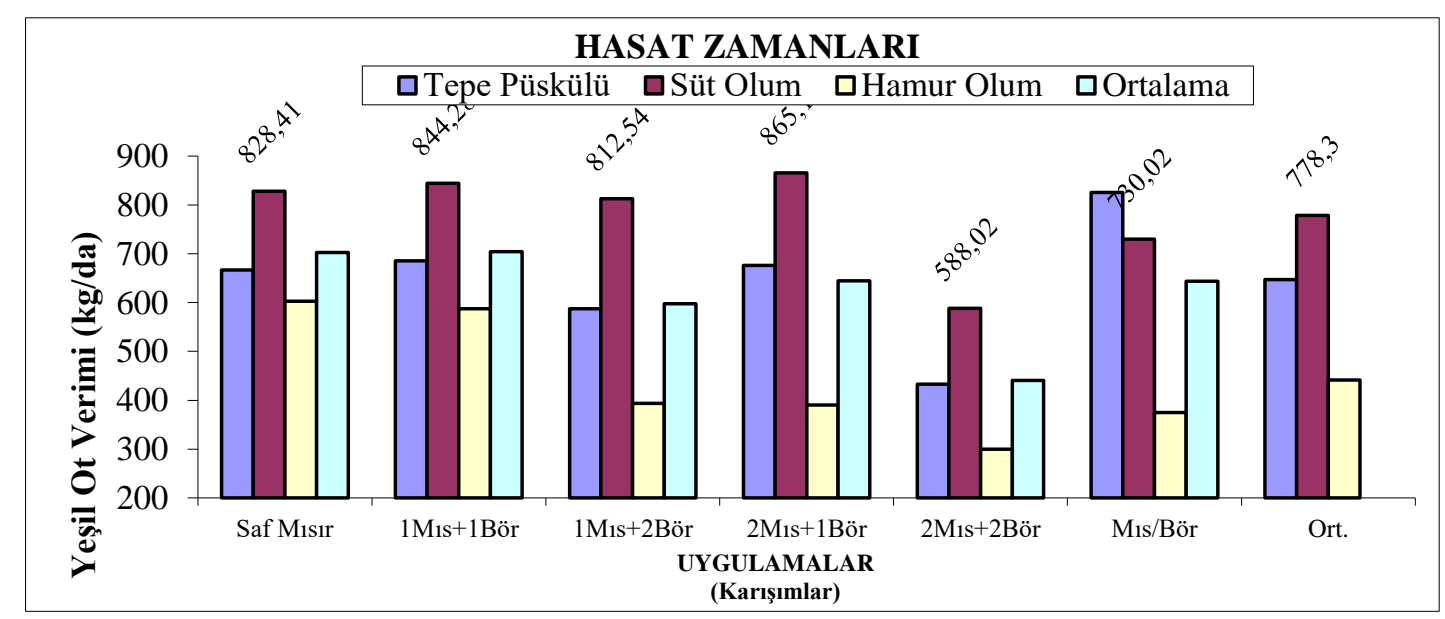

Şekil 3. Birlikte yetiştirme sistemlerinde ikinci ürün hâsıl mısırda yeşil ot verimi $(\mathrm{kg} / \mathrm{da})$ 


\section{Kuru Madde Verimi}

Kuru madde verimi karakterinin, varyans analiz sonucuna göre, hasat zamanında önemsiz, uygulamalar arasındaki farkın ise önemli çıktığı görülmektedir $(\mathrm{P}<0.05)$. Sonuçta, önemli çıkmamakla birlikte üretimde en yüksek kuru madde verimi 448.27 (kg/da) süt olum hasat zamanında gerçekleşmiştir. En yüksek değerlere saf misır (403.96 kg/da), $1 \mathrm{~m}+1$ börülce, $1 \mathrm{misır}+2$ börülce ve 2mısır+1börülce sistemlerinde en düşük değer, $(271.30 \mathrm{~kg} / \mathrm{da})$ ile $2 \mathrm{~m} 1 \mathrm{~s}$ ir+2 börülce sisteminde saptanmıştır (Şekil 4). Karışımdaki kuru madde verimi artışına ilişkinin bulgularımız Tansı (1987), Bilgen (1991) ile uyuşmaktadır. Bunun nedeni tür içi rekabet etkisinin türler arası rekabetten daha etkin olması sonucu misır bitkisinin daha iyi gelişebilmesi ve verimi etkileyen faktörlerden daha fazla yararlanmasiyla açılanabilir.

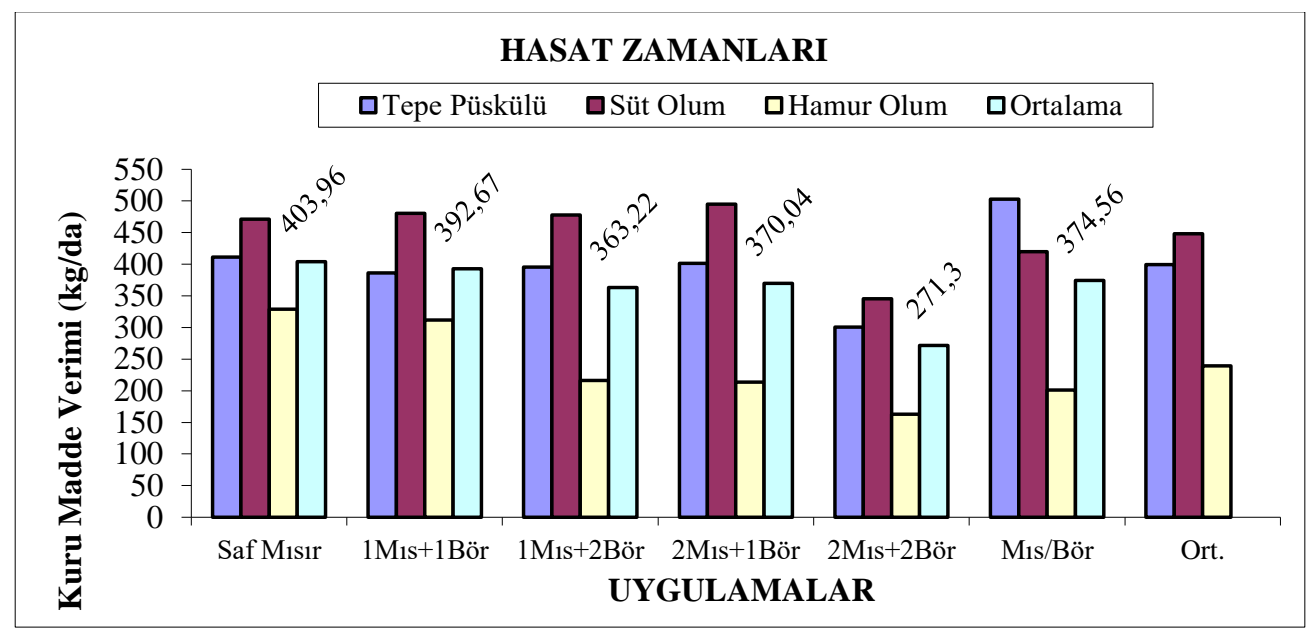

Şekil 4. Birlikte yetiştirme sistem. ikinci ürün hasıl mısırda kuru madde verimi $(\mathrm{kg} / \mathrm{da})$

\section{Ham protein verimi}

Ham protein verimi karakterinin yapılan varyans analiz sonuçlarına göre hasat zamanları arasında önemli bir farkın çıkmadı̆̆ 1 uygulamalarda ise $\% 5$ seviyesinde önemli çıktığı belirlenmiştir $(\mathrm{P}<0.05)$. Şekil 5'te ham protein verimi karakteri, yapılan L.S.D. testinde uygulamalarda 3 farklı grupların oluştuğu görülmektedir. Anılan karakterin 9.75-9.64 $\mathrm{kg} / \mathrm{da}$ arasında en yüksek değere ulaştığı gözlenmektedir. Börülcenin bulunduğu birlikte yetiştirme sisteminin azot içeriğini ve tanedeki azot oranını arttırdığını bildiren Muthuvel ve ark. (1984)'ün bulguları görüşümüzü destekler niteliktedir. 


\section{Börülce Bitkisinde}

\section{Bitki Boyu}

Bitki boyu karakterinin yapılan varyans analiz sonuçlarına göre uygulamalar arasındaki farkın önemli çıtığı görülmektedir $(\mathrm{P}<0.05)$. Hasıl börülcede bitki boyu karakterinin birlikte üretim sistemlerinden etkilendiği ve beş farklı grubun oluştuğu görülmektedir. En yüksek bitki boyu değerinin sırası ile saf Börülcede, misır/börülce sistemlerinden, en düşük değerin ise 1 misır+2börülce sisteminden elde edildiği Şekil 5'te izlenebilir. Bu durum, birlikte yetiştirmenin 1 şı rekabeti nedeni ile bitki boyunu arttırdığını ispat etmektedir. Benzer bulgular Tans1 (1987) tarafından bildirilmektedir. Ayrıca yerel börülcenin sarılıcı özelliğinden dolayı mısır bitkisi ile yarışmasında bitki boyunu arttırabilir. Benzer bulgular Bilgen (1991) ile uyumludur.

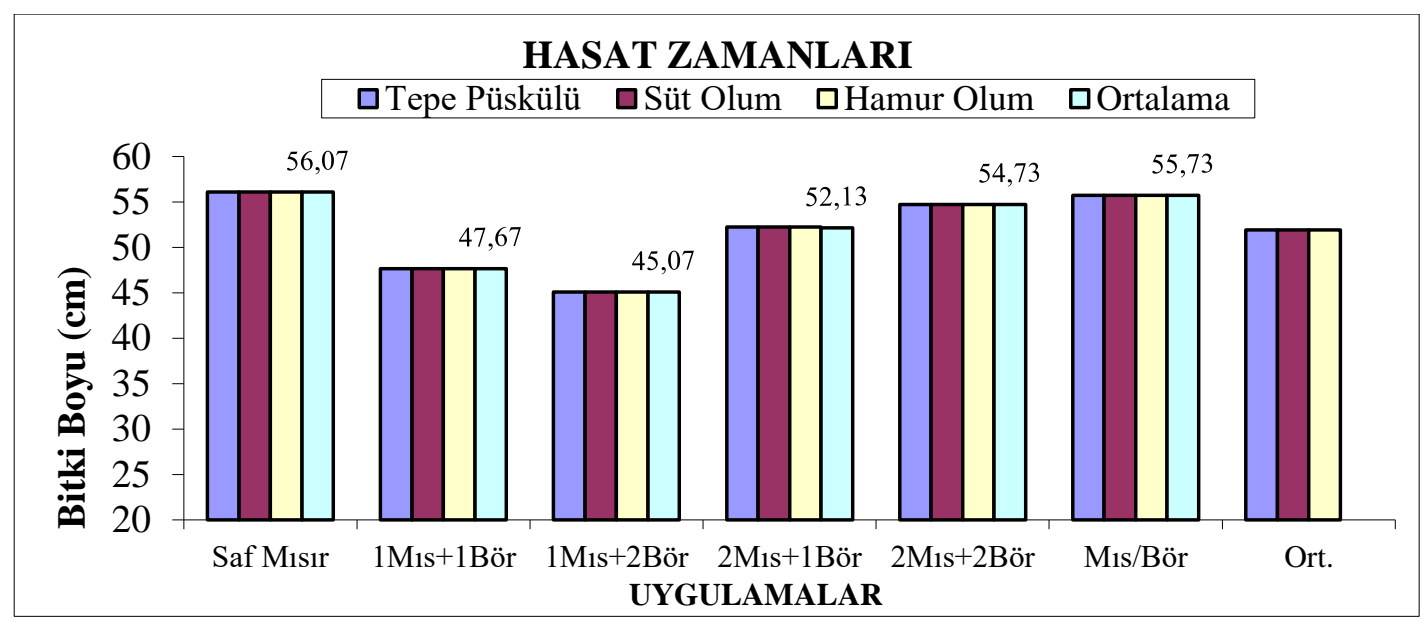

Şekil 5. Birlikte yetiştirme sistemlerinde ikinci ürün hasıl börülcede bitki boyu $(\mathrm{cm})$

\section{Dal Sayısı}

Dal sayısının yapılan $\mathrm{F}$ testi sonucuna göre uygulamalar ve bloklar arasında arasındaki farkın çok önemli bulunduğu gözlenebilir $\quad(\mathrm{P}<0.01)$ Uygulamalar incelendiğinde (Şekil 6), en yüksek dal sayıs1 değerinin 1.87-1.83 (adet/parsel) sirası ile saf börülce ve 2misır+2börülceden, en düşüğü 1.33 (adet/parsel)'lük değerle 2mısır+1börülce sisteminden elde edildiği saptanmıștır. Saf börülcede dal sayısının fazla oluşu, 1şık etkisinin dal sayısı karakterini arttırabileceğini bildiren Eser (1986)'in bulguları görüşümüzü desteklemektedir. 


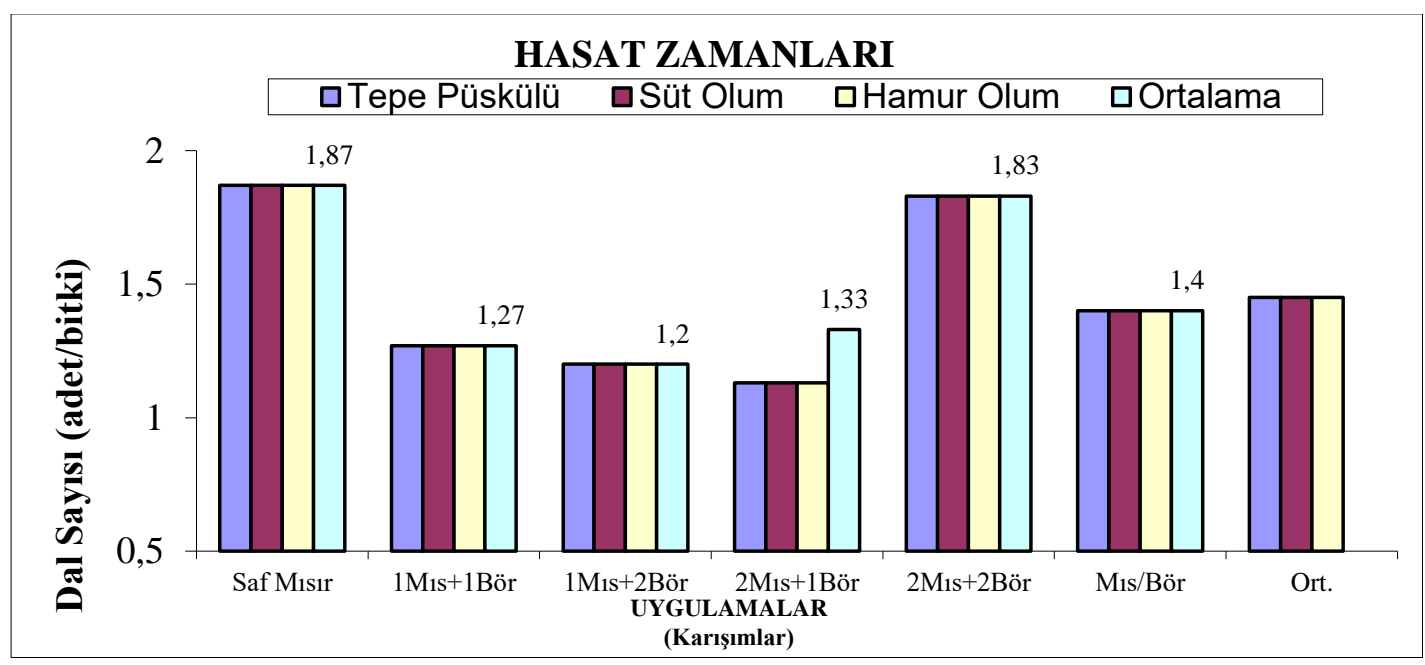

Şekil 6. Birlikte yetiştirme sistemlerinde ikinci ürün hâsıl börülcede dal sayısı

\section{Yeşil Ot Verimi}

Yeşil ot verimine ait karakterinin yapılan varyans analiz testine göre hasat zamanı ve uygulamalar arasındaki farkın çok önemli çıktığı görülebilir $(\mathrm{P}<0.01)$. Uygulamalarda elde edilen bulgulara göre en yüksek yeşil ot veriminin saf börülcede, en düşüğü ise 2misır+2börülce olduğu Şekil 6'da izlenebilir. Hasat zamanlarına göre en yüksek değerin $55.35-54.22 \mathrm{~kg} / \mathrm{da}$ ile tepe püskülü ve süt olumundan, en düşük değerin ise hamur olumunda saptanmıştır. Az 1ş1klı yerde yetişen bitkilerde kuru madde oranı çok 1 şılıl yerde yetişen bitkilere oranla 2-2.5 katı daha az kuru madde oluşturabileceğini bildiren Eser (1986) ile bulgularımız uyuşmaktadır. Ayrıca birlikte yetiştirme sistemlerinde baklagillerin kuru madde miktarının azaldığını bildiren Vahua ve Miller (1978) ile bulgularımız uyuşmaktadır.

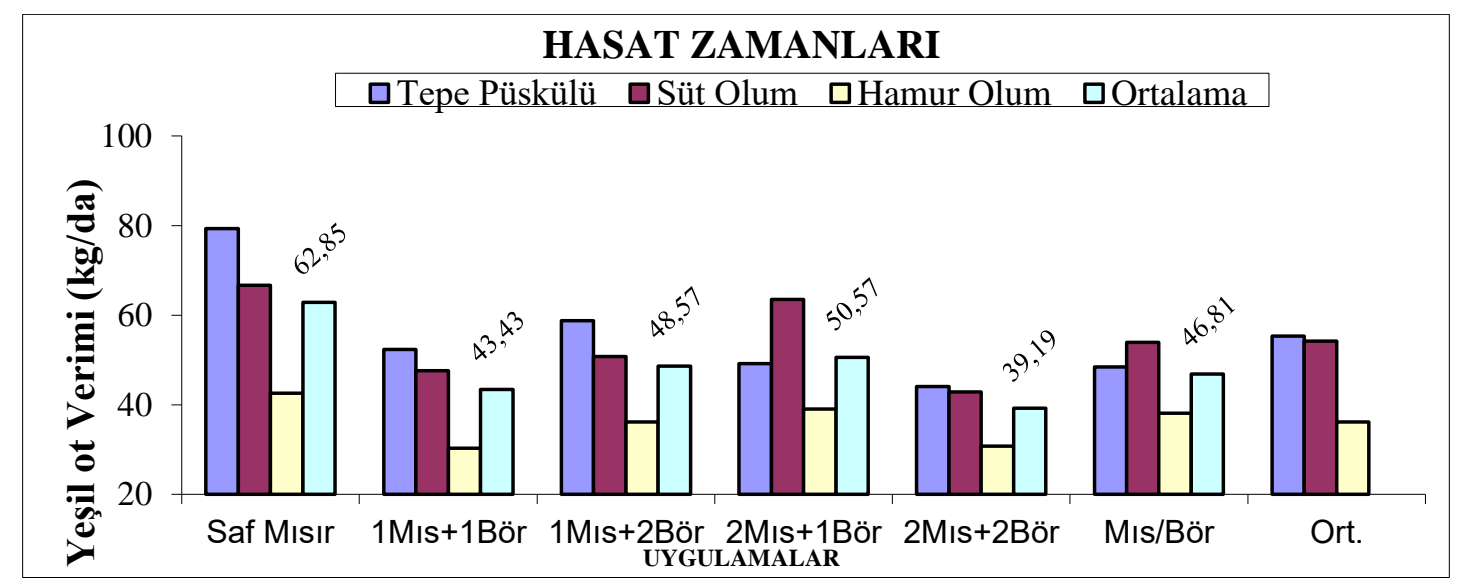

Şekil 6. Birlikte yetiştirme sistemlerinde ikinci ürün hasıl börülcede yeşil ot verimi $(\mathrm{kg} / \mathrm{da})$ 


\section{Kuru Madde Verimi}

Kuru madde verimi ait yapılan varyans analiz sonuçlarına göre hasat zamanı ve uygulamalarda çok önemli $(\mathrm{P}<0.01)$, tekerrürlerde ise önemli olduğu bulunmuştur $(\mathrm{P}<0.05)$. Şekil 7'de hasat zamanın süt olum devresinde $9.43 \mathrm{~kg} / \mathrm{da}$ ile en yüksek, 6.08 kg/da ile en düşük hamur olum devresinde tespit edilmiştir. Anılan karakterin uygulamalarda en yüksek 10.10 $\mathrm{kg} /$ da ile saf börülcede, en düşüğün ise 6.32 $\mathrm{kg} / \mathrm{da}$ ile $2 \mathrm{misır}+2$ börülcede olduğu Şekil 7'de görülebilir. Bol 1şıklı yerde yetişen bitkilerde kuru madde oranı az 1şıklı yerde yetişen bitkilere oranla 2-2,5 katı daha fazla kuru madde oluşturabileceğini bildiren Eser (1986) ile bulgularımız uyuşmaktadır.

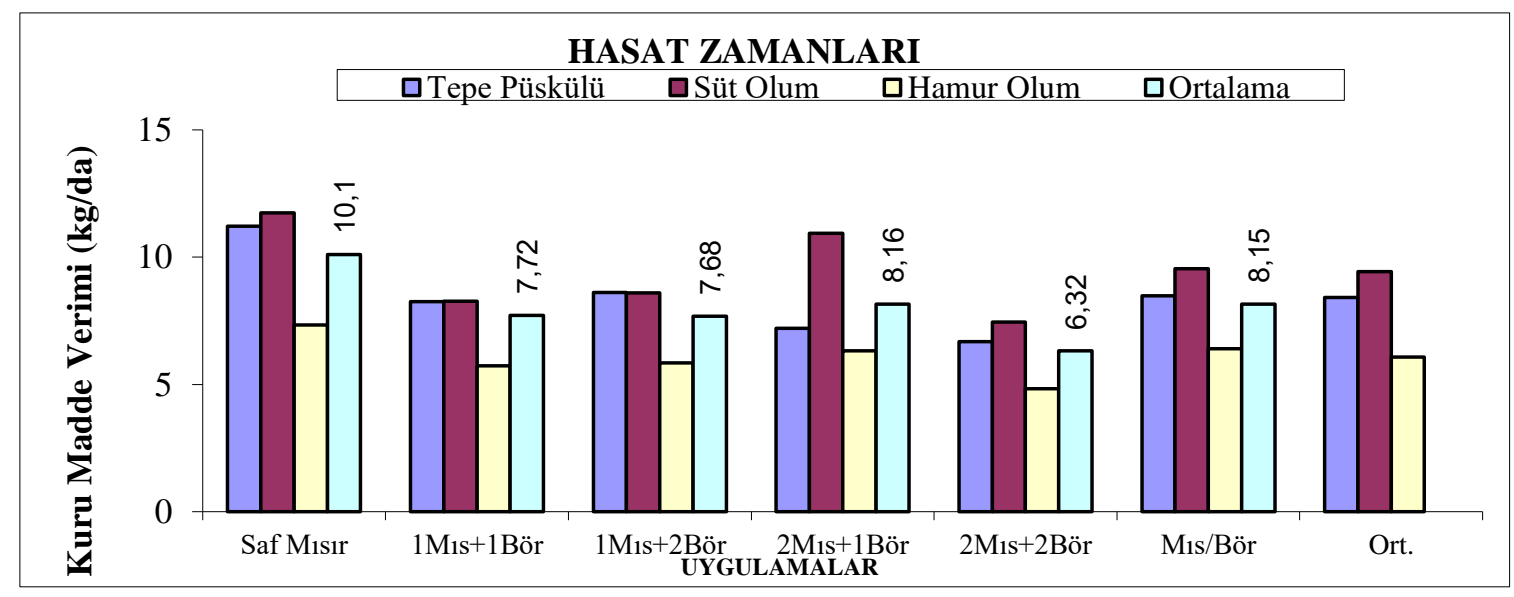

Şekil 7. Birlikte yetiştirme sistemlerinde ikinci ürün hasıl börülcede kuru madde verimi (kg/da)

\section{Ham Protein Verimi}

Ham protein verimi karakterinin varyans analiz sonucuna göre bloklar hasat zamanı ve uygulamalar arasındaki farkın çok düzeyinde çok önemli çıktığı Şekil 8'den izlenebilir $(\mathrm{P}<0.01)$. Hasat zamanı dikkate alındığında en yüksek ham protein verimi değerinin $19.04(\mathrm{~kg} / \mathrm{da})$ tepe püskülünde, uygulamalarda ise en yüksek $16.50 \mathrm{~kg} / \mathrm{da}$ ile 1 misır+1börülcede, $15.94 \mathrm{~kg} /$ da ile saf börülcede saptanmıştır. Birlikte yetiştirme sistemleri ham protein oranından olumlu etkilendiği Şekil 8'den izlenebilir. En düşük değer misır/börülce sistemlerinde saptanmıştır. Tür içi rekabetinden dolayı bol 1şı̆ga kavuşan bitkilerin tanelerinde protein oranının artabileceğini, ayrıca karışımlarda azalan 1şık yoğunluğunun ham protein içeriğinin azaltacağını belirten Eser (1986) ile uyum içindedir. 


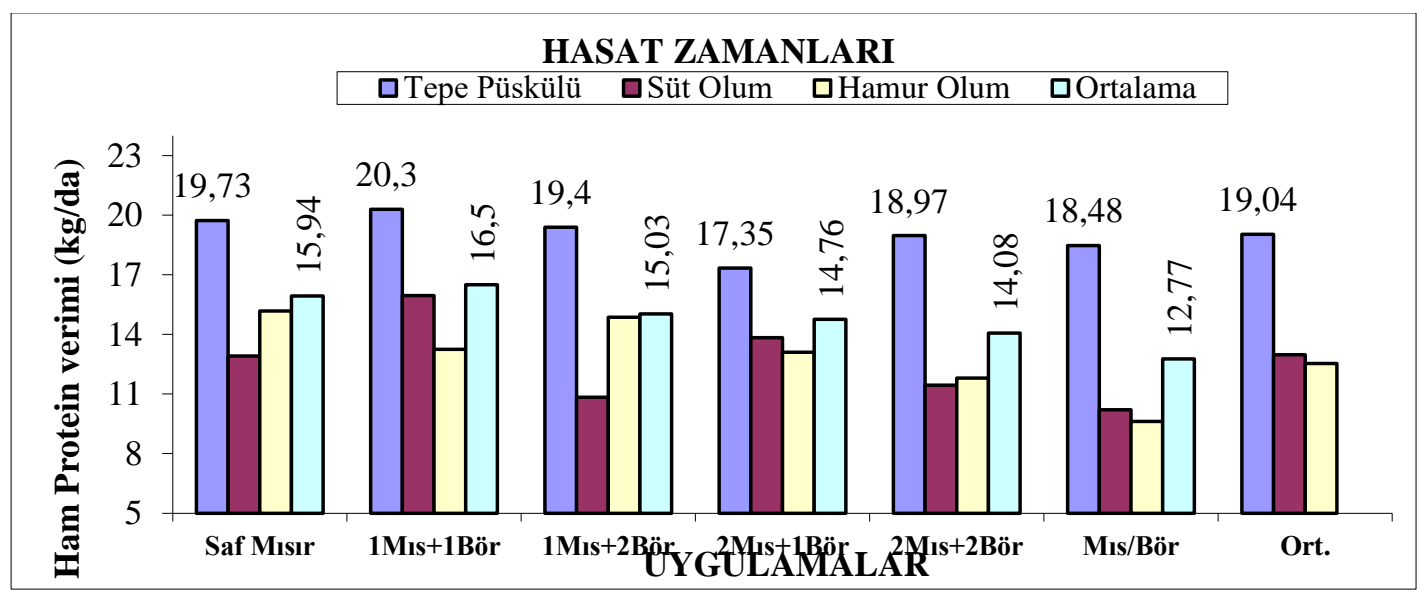

Şekil 8. Birlikte yetiştirme sistem. ikinci ürün hasıl börülcede ham protein verimi $(\mathrm{kg} / \mathrm{da})$

\section{SONUÇ ve ÖNERÍLER}

Güneydoğu Anadolu'da, İkinci üründe hasıl amacıyla birlikte yetiştirilen misır ve börülcenin farklı ekim sistemlerinde bazı tarımsal karakterler ile kalite özelliğine etkisini incelemek amaciyla yürütülen bu çalışmada, incelenen özellikler koçan oranı hariç birlikte üretim sistemlerinden önemli ölçüde etkilenmiştir. İkinci üründe börülce veriminin azaldığ 1, misır veriminin arttığ alan kullanım etkinliğinin bir ölçüsü olan LER'in karışım ekimlerde kaynakları daha etkin kullanmıştır. Toprak kaynakları sınırlı olan küçük işletme sahipleri bu ülkelerde, mevcut kaynakları daha iyi kullanmakla en az iki farklı bitkiyi birlikte yetiştirerek risk unsurunu azaltabildiği, toprak verimliliğini koruduğu, erozyonu önleyip daha iyi yabancı ot kontrolüne olanak tanıdığ hastalık ve zararlı epidemisini azaltıp aile iş gücünün daha verimli kullanılmasına olanak sağlayarak karlılığg artırdığgndan dolayı birlikte yetiştirme tercih edilmelidir.

\section{KAYNAKÇA}

Anonim, 2002. Şanlıurfa Meteoroloji Bölge Müdürlüğü Aylık Hava Raporları.

Bengisu, H., Baytekin, H. 2020a. Harran ovası sulu koşullarda ikinci ürün olarak yetiştirilen üç mısır çeşidinde bitki sıklığının verim ve bazı tarımsal karakterlere etkileri üzerine bir araştırma. Euroasia Journal of MathematicsEngineering Natural \& Medical Sciences, 8: $137-145$.

Bengisu, H., Baytekin, H. 2020b. Harran ovası sulu koşularında ikinci ürün olarak yetiştirilen mısırda verim ve tarımsal karakterlerin belirlenmesi. EJONS International Journal on Mathematics, Engineering \& Natural Sciences 13:125131.

Bilgen, M., Sağlamtimur, T., Tansı, V. 1991. Antalya ovası koşullarında mısırın üç 
değişik baklagil ile birlikte yetiştirilme olanakları üzerinde araştırmalar. Türkiye

2. Çayır-Mer'a ve Yem Bitkileri Kongresi İzmir s. 379-389.

Çelik, B., Bengisu, G. 2019. Harran ovası sulu koşullarında ikinci ürün olarak yetiştirilen iki mısır çeşidinde farklı azot dozlarının hasıl ve tane verimi ile bazı tarımsal karakterlere etkileri üzerine bir araştırma. Euroasia Journal of Mathematics-Engineering Natural \& Medical Sciences, 7: 95-99.

Dinç, U., Özbek, H., Yeşilsoy, P., Çolak, A.K., Derici, R. 1988. Harran ovas1 toprakları. Çukurova Üniversitesi Ziraat Fakültesi Toprak Bölümü, TÜBİTAKTOAG 534 No'lu Proje, Adana.

De, R., Singh,. S. 1981. Management Practices for intercropping systems. P. 1721. Proc. İnt. Workshap On İntercropping, 10-13 Jan. 179. ICRISTA, Hyderabad, India.

Eser, D. 1986. Tarımsal Ekoloji. Ankara Üniversitesi Ziraat Fakültesi Yayınları No:287 Ankara Üniversitesi Basımevi, ANKARA.

Haizel, K.A. 1974. The Agronomic significance of mixed cropping. 1.Maize interplanted with cowpea. Ghana J. Agric Sci. 7: 169-178.
Seydoşoğlu, S., Saruhan, V. 2017. Farklı ekim zamanlarının bazı silajlık mısır çeşitlerinde verim ve verim unsurlarına etkisinin belirlenmesi (Doktora Tezi). Ege Üniversitesi Ziraat Fakültesi Dergisi, 54(4):377-383.

Seydoşoğlu, S., Cengiz, R. 2020. İkinci ürün olarak yetiştirilen silajlık mısır çeşitlerinde farklı ekim zamanları ile FAO olum gruplarının verim ve verim unsurlarına etkisinin belirlenmesi. Euroasia Journal of Mathematics-Engineering Natural \& Medical Sciences, 8: 117-125.

Sarikurt, B., Bengisu, G. 2020. Diyarbakır sulu koşullarında II. ürün olarak yetiştirilen bazı mısır çeşitlerinde verim ve bazı tarımsal karakterler ile karakterler arası ilişkilerin belirlenmesi. Avrupa Bilim ve Teknoloji Dergisi, (18): 243-247.

Wahua, T.A.T., Miller, D.A. 1978. Relative yield totals and yield components of intercropped sorghum and soybeans. Argon. J., (70):287-291.

Yıldırım, K., Bengisu, G. 2019. Bazı tane sorgum ve sorgum $\mathrm{x}$ sudanotu melezi çeşitlerinde ekim zamanının verim ve verim unsurlarına etkisi üzerine bir araştırma. ISPEC Tarım Bilimleri Dergisi 3(1): 9-18. 